\title{
Analisis Indeks Pencemaran Air Tanah di DKI Jakarta dengan Interpolasi Spasial
}

\author{
(Analysis of Groundwater Pollution Index in DKI Jakarta using Spatial \\ Interpolation)
}

\author{
Dimas Ardi Prasetya ${ }^{1 *}$, I Putu Santikayasa ${ }^{2}$, dan Iqbal Hanun Azizi ${ }^{3}$ \\ ${ }^{1}$ Teknik dan Manajemen Lingkungan, Sekolah Vokasi, Institut Pertanian Bogor. \\ J1. Kumbang No 14, Kampus IPB Cilibende, Bogor, Jawa Barat Indonesia \\ ${ }^{2}$ Departemen Geofisika dan Meteorologi, Fakultas Matematika dan Ilmu Pengetahuan Alam, \\ Institut Pertanian Bogor. \\ J1. Raya Dramaga, Kampus IPB Dramaga, PO BOX 220, Bogor, Jawa Barat Indonesia \\ ${ }^{3}$ Departemen Teknik Geodesi Fakultas Teknik, Universitas Gadjah Mada. \\ Jl. Grafika Bulaksumur No.2, Senolowo, Sinduadi \\ * Penulis korespondensi: dimas_arpras@apps.ipb.ac.id
}

\begin{abstract}
Everyone needs water to his life and his activity. Groundwater pollution is one of the problems in Indonesia. The increasing number of the show an increase water needs. They were filled with groundwater needs. There has been decreasing groundwater that is occupied in quantity and quality. The research was done in Jakarta, consisting of 42 sub-district. Research takes into account the condition of the dry season. Uses index research quality of groundwater pollution. Monitoring parameter groundwater consisting of physics, chemical and biology parameter. The research consists of determining the pollution index in Jakarta, analysis of groundwater pollution, and predicted entanglement with an index pollution population density. The research uses spatial interpolation to determine locations. Pollution index calculation used calculation storet. The measurement results in the rate used in the analysis index groundwater pollution. The research results obtained index value has increased pollution are on the north and central of Jakarta. The research results obtained East Jakarta having the condition geology that porous. The value of the groundwater pollution index was in north Jakarta. The results of the study indicated by a map pollution index the quality of groundwater during three periods. Index pollution in Jakarta consisting of pollution until the same as the quality standard. Research shows the absence of correlation with the population with the pollution groundwater quality.
\end{abstract}

Keyword: index, groundwater, parameters, quality

\section{PENDAHULUAN}

Sumber daya air merupakan kebutuhan pokok manusia untuk melangsungkan kehidupannya. Air sangat berperan dalam berbagai kebutuhan dan pemanfaatan seperti kebutuhan untuk domestik maupun industri. Air tanah merupakan salah satu potensi sumberdaya air yang belum dimanfaatkan dengan optimal dan bijak. Air bersih merupakan kebutuhan pokok manusia, dalam hal ini air bersih adalah air tanah. Kebutuhan air bersih merupakan kebutuhan pokok yang tidak dapat diganti dan ditinggalkan oleh sebab itu pengolahan dan pelestarian air merupakan hal yang mutlak diperlukan. Meningkatnya permintaan untuk air, standar hidup yang lebih tinggi, 
berkurangnya kualitas sumber daya yang dapat diterima, pencemaran air oleh perkotaan, pertanian, dan industri telah menyebabkan lingkungan menjadi buruk (Karamous, M 2011).

Meningkatnya jumlah penduduk maka akan menyebabkan peningkatan potensi jumlah penggunaan air tanah. Peningkatan jumlah penduduk, maka kebutuhan air minum juga semakin meningkat. Peningkatan kebutuhan air tersebut tidak diiringi dengan ketersedian air baku yang memadai secara kuantitas dan kualitas.

Terdapat banyak manfaat air tanah bagi kehidupan makhluk hidup, bukan hanya manusia yang memanfaatkan air tanah, tetapi juga tumbuhan dan hewan. Air tanah biasa digunakan untuk memenuhi kebutuhan sehari-hari, misalnya untuk mandi, air minum, dan sebagainya. Air tanah merupakan sumber air minum utama bagi masyarakat Indonesia. Tumbuhan juga sangat memerlukan air tanah, karena air tinggal di dalam tanah, dan sangat bergantung pada ketersediaan air tanah.

Daerah Khusus Ibu Kota (DKI) Jakarta merupakan daerah dengan jumlah kepadatan penduduk yang tinggi, hal semacam ini juga memacu pemerintah dalam hal penyediaan potensi air. Air tanah yang dimanfaatkan oleh masyarakat tentunya harus memiliki debit yang mencukupi dan kualitas yang baik. Jumlah kepadatan penduduk yang tinggi akan menyebabkan prakiraan penurunan kualitas air tanah. Penurunan kualitas air tanah yang terjadi diperkirakan oleh aktivitas masyarakat yang kurang bijak dalam pengelolaan sumber air tanah.

Sumber air tanah sudah terlihat mengalami penurunan kualitas di wilayah DKI Jakarta. Beberapa titik menunjukkan air sudah tercemar oleh septic tank. Hal ini terjadi karena posisi sumur terlalu dekat dengan septic tank ataupun sumur-sumur yang terbuka mengalami pencemaran saat terjadi banjir. Dalam hal ini, hasil air tanah menyebarkan kontaminan air tanah melalui akuifer di sepanjang alirannya.

Analisis air tanah menggunakan indeks pencemaran air berguna untuk mendapatkan kondisi umum ai tanah di lokasi pengukuran. Pengukuran indeks pencemaran air tanah menujukkan kondisi kualitas air tanah. Semakin tinggi nilai pencemaran air tanah akan menunjukkan nilai kualitas air tanah semakin rendah.

Analisis spasial merupakan tahapan untuk menentuhkan pola sebaran kualitas air tanah di suatu lokasi dan keterwakilan titik pengukuran. Hasil dari bentuk analisis spasial akan menujukkan pendekatan yang nantinya akan digunakan dalam proses pemetaan kualitas air tanah berdasarkan nilai indeks pencemaran.

Penelitian yang dilakukan memiliki tujuan diantaranya adalah menentukan indeks pencemaran air tanah di DKI Jakarta dan menentukan korelasi kepadatan penduduk dengan indeks pencemaran air tanah di DKI Jakarta.

\section{METODE PENELITIAN}

Penelitian dengan judul Analisis Indeks Pencemaran Air tanah di DKI Jakarta dengan Interpolasi Spasial. Penelitian dilakukan pada 42 Kecamatan. Penelitian dilakukan dengan mengumpulkan data primer berupa data parameter kualitas air dari sumur masyarakat dan pengumpulan data sekunder berupa data peta geologi dan hidrogeologi. Metode pengolahan menggunakan bantuan perangkat lunak GIS 10.0. Penentuan pendekatan lokasi menggunakan interpolasi spasial. Penentuan indeks pencemaran air tanah 
menggunakan Rumus Indeks Pencemaran.

\section{Indeks Pencemaran}

Indeks kualitas air adalah mekanisme matematis untuk menghitung data kualitas air menjadi istilah sederhana, misalnya kondisi baik, tercemar ringan, tercemar sedang dan tercemar berat. Kelas kualitas air didefinisikan tergantung parameter fisik, biologi dan kimia yang diukur selain untuk keperluan air yang digunakan seperti air minum, air untuk pertanian, air untuk industri. Data indeks ini penting untuk menggambarkan status kualitas air secara umum yang dapat sangat membantu dalam memilih Teknik pengolahan air yang sesuai untuk mengatasi masalah kontaminasi.

Metode Indeks Kualitas Air yang sering dipakai di Indonesia adalah metode Indeks Pencemaran (IP) dan Metode Storet yang mengacu pada Kepmen LH no. 115 Tahun 2003 tentang pedoman penentuan status mutu air. Metode Indeks Pencemaran diperhitungkan berdasarkan dua indeks kualitas yaitu Indeks Rata-Rata (IR) dan Indeks Maksimum (IR). Indeks RataRata menunjukkan data pencemaran rata-rata dari seluruh parameter dalam satu kali pengamatan. Indeks Maksimum adalah nilai dominan dari seluruh parameter dalam satu kali pengamatan. Perhitungan indeks pencemaran dihitung menggunakan rumus :

$\mathrm{IPj}=\sqrt{\frac{\left(\frac{c_{i}}{L_{i j}}\right)_{M}^{2}+\left(\frac{C_{i}}{L_{i j}}\right)_{R}^{2}}{2}}$

Dimana :

$\begin{array}{ll}\mathrm{IPj} & : \text { Indeks Pencemaran } \\ \mathrm{Ci} & : \text { Konsentrasi hasil uji } \\ & \text { parameter } \\ \mathrm{Lij} & : \text { Konsentrasi parameter }\end{array}$

sesuai baku mutu peruntukan air $\mathrm{j}$

(Ci/Lij)M : Nilai Ci/Lij maksimum

$(\mathrm{Ci} / \mathrm{Lij}) \mathrm{R} \quad$ : Nilai Ci/Lij rata-rata

Pengumpulan data penelitian merupakan tahapan yang dilakukan untuk menganalisis indeks pencemaran air tanah di DKI Jakarta dilakukan pada pertengahan (peralihan) musim yaitu penghujan dan kemarau. Pengukuran dilakukan pada keterwakilan pada Bulan Mei. Data yang dikumpulkan adalah data air tanah pada zona unconfine aquifer. Data yang dikumpulkan adalah data parameter fisika, kimia dan biologi yang akan dianalisis menggunakan persamaan Storet sehingga akan didapatkan indeks kualitas air tanah. Data parameter fisika terdiri dari kekeruhan, warna, TDS; parameter kimia terdiri dari $\mathrm{pH}$, kesadahan, DO; parameter biologis terdiri dari Total Coliform. Data yang dihimpun kemudian ditentukan kategori indeks pencemaran air tanah. Data yang disajikan adalah data gambaran persebaran indeks pencemaran air tanah pada beberapa lokasi di DKI Jakarta.

Penentuan interpolasi spasial dilakukan untuk pendekatan keterwakilan lokasi penelitian. Interpolasi spasial dilakukan dengan beberapa metode diantaranya menggunakan Nearest Neighbor Interpolation, Fixed Radius - Local Averaging, Inverse Distance Weighted Interpolation, Splines interpolations.

\section{HASIL DAN PEMBAHASAN}

\section{Analisis Interpolasi Spasial}

Analisis interpolasi spasial digunakan untuk menentukan perwakilan dan prediksi sebaran polutan pada air tanah yang dipantau. Pengukuran dilakukan pada 42 Kecamatan dengan 267 Titik Pemantauan. 
Pendekatan interpolasi yang berbeda umumnya memberikan hasil yang berbeda walaupun menggunakan data yang sama sebagai input. Hal ini disebabkan oleh perbedaan algoritma matematis yang dipergunakan dalam melakukan interpolasi. Setiap pendekatan yang dipergunakan dapat dievaluasi dengan menggunakan nilai akurasi dengan membandingkan nilai interpolasi dengan nilai observasi pada titik-titik lokasi yang tidak digunakan dalam proses interpolasi.

\section{Nearest Neighbor Interpolation}

Nearest Neighbor Interpolation ini dikenal juga dengan nama interpolasi poligon Thiessen. Nilai dari wilayah yang diestimasi diperoleh dari nilai titik sampel terdekat. Pendekatan ini merupakan pendekatan yang paling sederhana. Sesuai dengan pendekatan yang digunakan, asumsinya adalah suatu wilayah memiliki nilai yang seragam sesuai dengan data yang ada paling dekat. Hasil analisis dengan pendekatan Nearest Neighbor Interpolation akan menghasilkan pola interpolasi (Gambar 1).

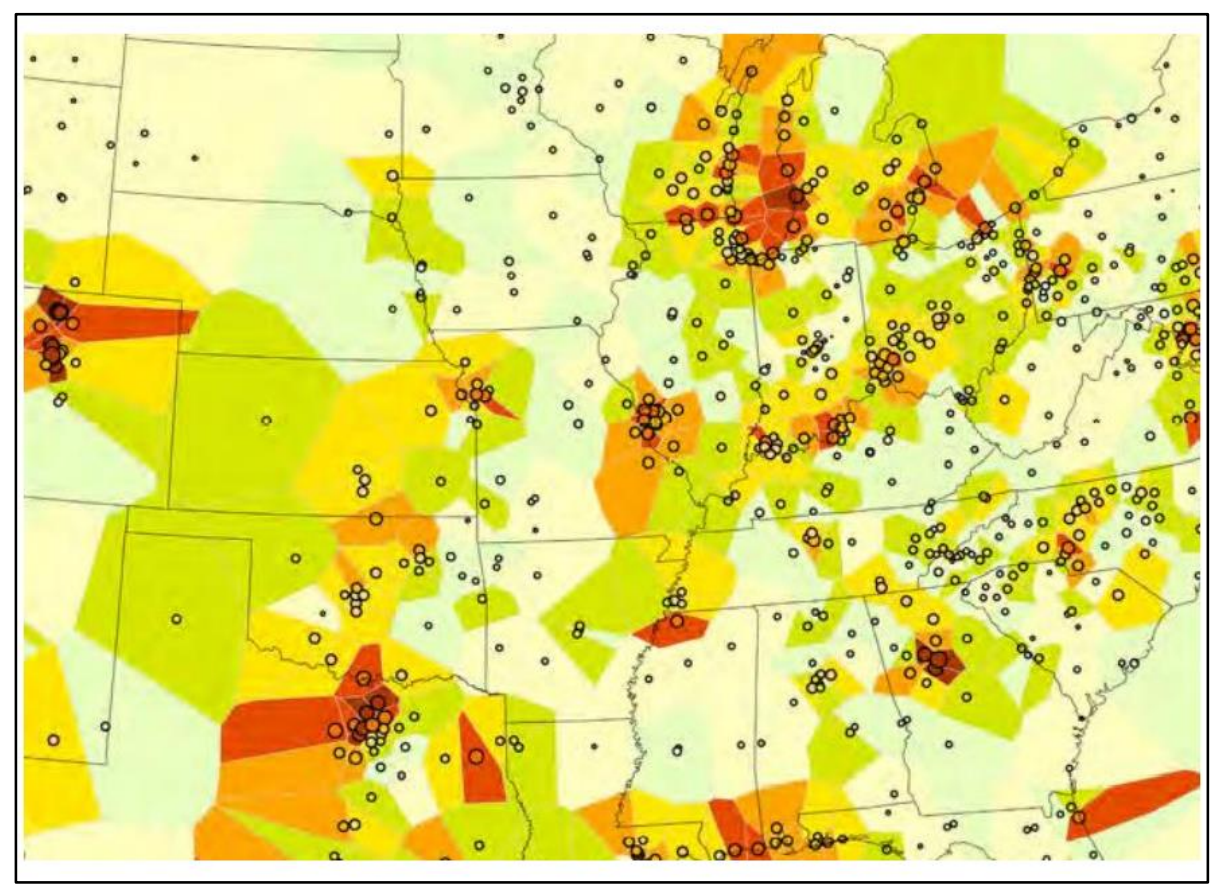

Gambar 1 Pola Interpolasi Menggunakan Pendekatan Nearest Neighbor Interpolation

\section{Fixed Radius - Local Averaging}

Fixed Radius - Local Averaging menggunakan asumsi bahwa nilai suatu wilayah yang diestimasi memiliki keterkaitan hanya pada jarak tertentu dibandingkan dengan hasil observasi. Sehingga penentuan nilai diperoleh dari nilai rataan dari wilayah yang dilingkupi pada radius yang ditentukan. Penggunaan pendekatan ini lebih kompleks dari pendekatan Nearest Neighbor Interpolation namun lebih sederhana dari pendekatan lainnya. Hasil analisis dengan pendekatan Fixed Radius - Local Averaging akan menghasilkan pola interpolasi (Gambar 2). 


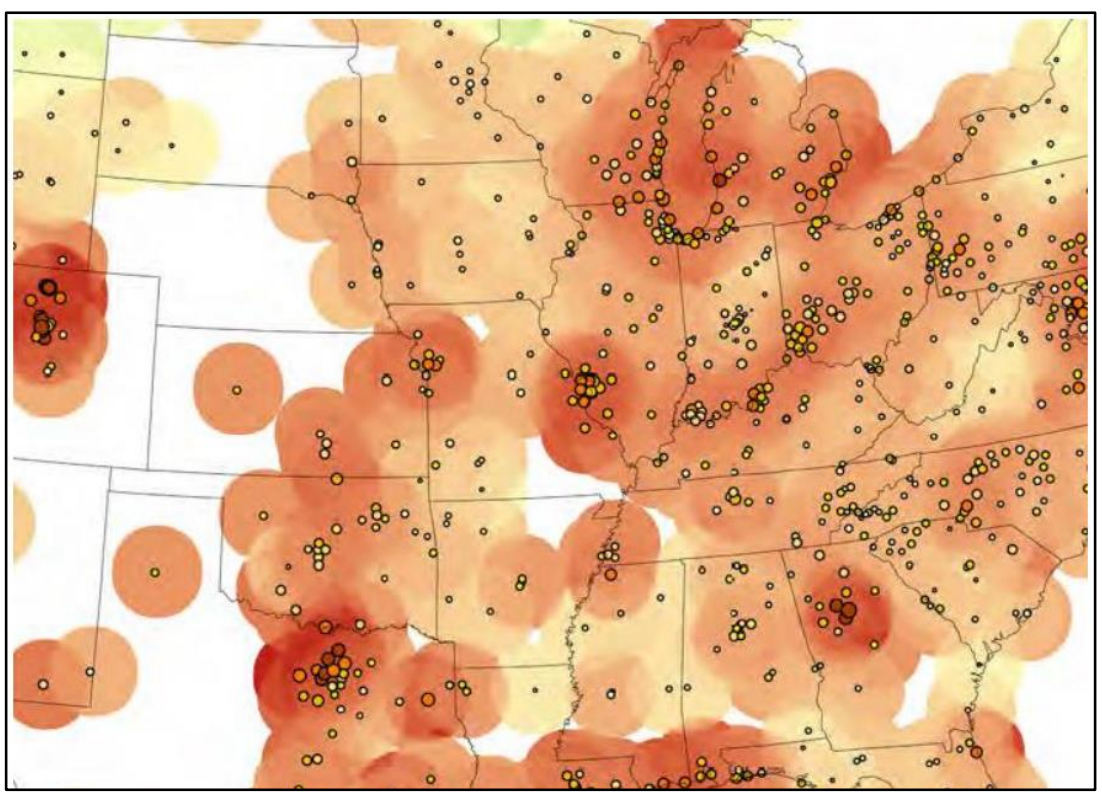

Gambar 2 Pola Interpolasi Menggunakan Pendekatan Fixed Radius - Local Averaging

\section{Inverse Distance Weighted dengan jarak dari titik observasi.} Interpolation

Inverse Distance Weighted Interpolation atau interpolasi dengan pembobotan menggunakan data hasil observasi dan jarak sebagai bobot untuk menentukan nilai estimasi. Bobot dari masing-masing hasil nilai berkebalikan Semakin tinggi jarak maka bobot yang diberikan semakin rendah dan demikian juga sebaliknya, semakin pendek jarak maka bobot yang diberikan semakin tinggi. Hasil analisis dengan pendekatan Inverse Distance Weighted Interpolation akan menghasilkan pola interpolasi (Gambar 3).

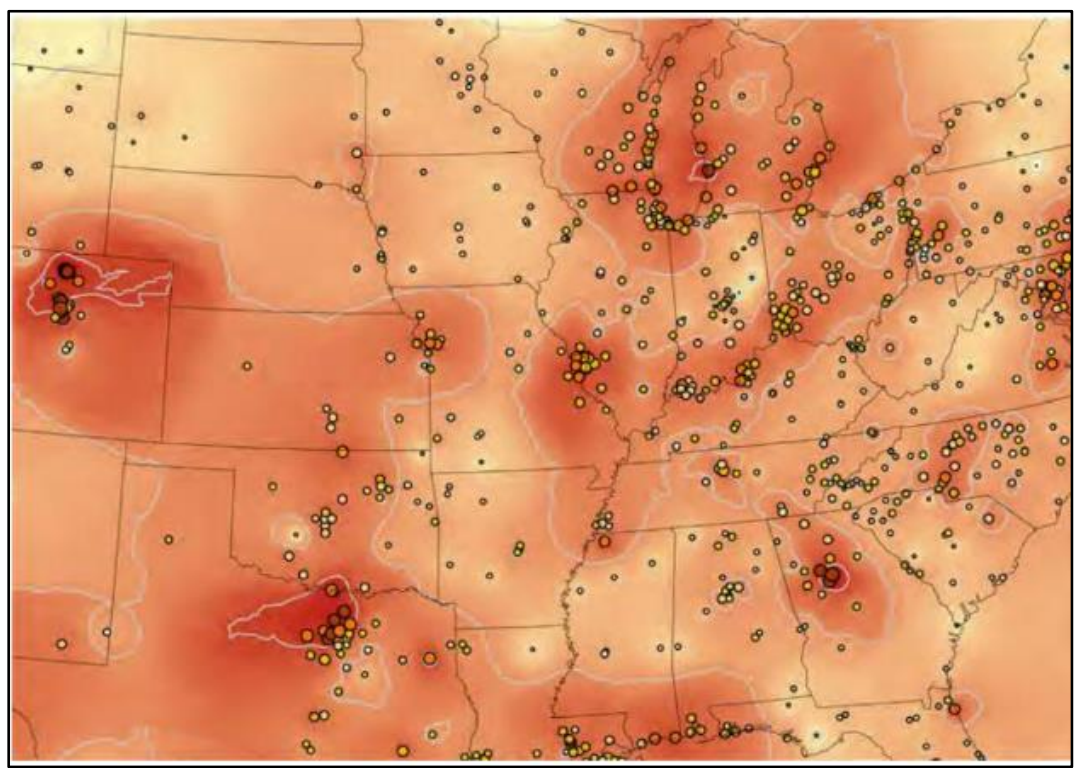

Gambar 3 Pola Interpolasi Menggunakan Pendekatan Inverse Distance Weighted Interpolation 


\section{Splines interpolations}

Splines interpolations dengan menggunakan splines menggunakan pendekatan seperti proses smoothing pada data 1 dimensi. Splines berasal dari spatial lines dengan menggunakan algoritma fungsi polynomial tertentu untuk mendapatkan nilai sesuai dengan nilai-nilai observasi. Pendekatan statistik digunakan untuk mendapatkan nilai yang sesuai dalam proses fitting menggunakan data observasi. Hasil analisis dengan pendekatan Splines interpolations akan menghasilkan pola interpolasi (Gambar 4).

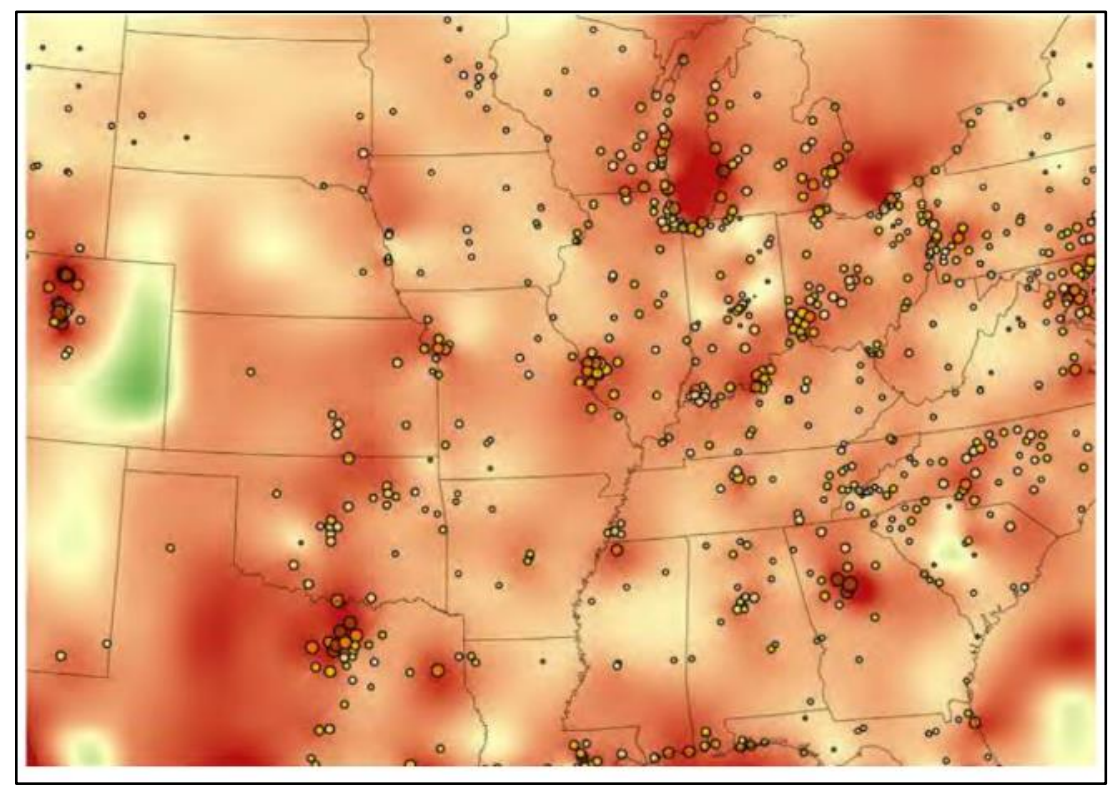

Gambar 4 Pola Interpolasi Menggunakan Pendekatan Splines interpolations

Pendekatan interpolasi spasial menunjukkan adanya kerapatan titik pengukuran akan menyebabkan adanya keterwakilan yang baik. Pendekatan interpolasi spasial menggambarkan semakin rapat lokasi pengukuran akan menyebabkan radius keterwakilan semakin rapat.

\section{Aspek Geologi dan Hidrogeologi}

Kondisi geologi menunjukkan formasi batuan wilayah kajian terdiri dari QTvb, Qa, Qav, Qbr. Dominasi struktur geologi wilayah kajian adalah QTvb dan Qa. Formasi QTvb merupakan formasi yang terdiri dari Tuf, tuf batu apung, batu pasir tufaan. Formasi Qav merupakan formasi batuan yang terdiri dari Lempung, lanau, pasir, kerikil, kerakal dan bongkah. Pergerakan air laut untuk masuk ke daratan sangat mungkin terjadi. Pergerakan ini berasal dari arah utara DKI Jakarta menuju ke Selatan.

Pergerakan air laut dimungkinkan terjadi karena adanya pengambilan air tanah pada sektor-sektor industri atau instansi yang memanfaatkan air tanah dengan potensi yang besar. Disamping itu kondisi formasi geologi daerah setempat juga yang bersifat porous atau dapat meloloskan air menjadi salah satu faktor salinitas terjadi (Gambar 5). Berdasarkan peta geologi dapat memprediksi bahwa air tanah pada umumnya memungkinkan sebagai sarana pencemaran air tanah. 


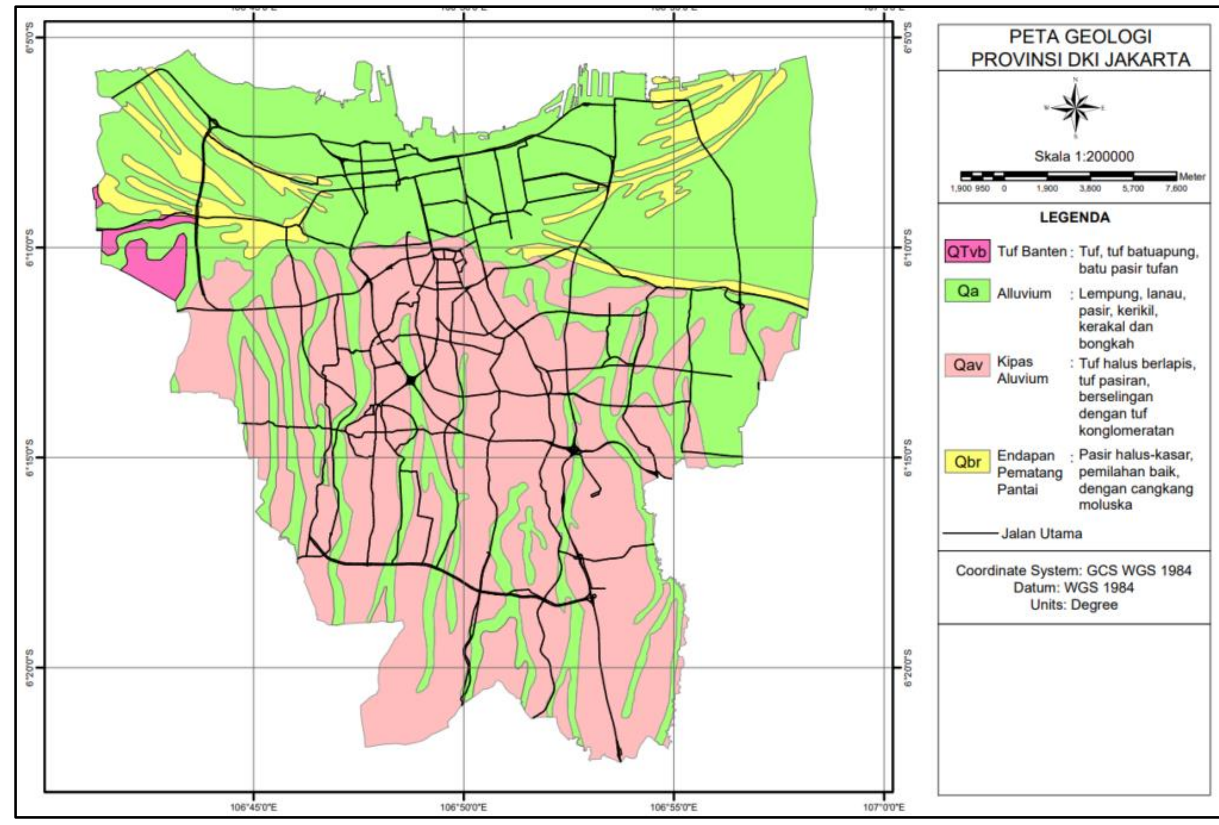

Gambar 5 Peta Geologi DKI Jakarta

Dari peta hidrogeologi (Gambar 6) menunjukkan adanya potensi sumber air tanah pada wilayah lokasi kajian menunjukkan tingkat kelulusan air yang cukup tinggi. Tingkat kelulusan air berkisar 5- 25 liter/detik. Masing-masing zona akuifer pada DKI Jakarta bervariasi dari kedalaman sekitar 20-60 m, 60-150 $\mathrm{m}$, dan 150-250 m di bawah muka tanah setempat. Kondisi hidrogeologi permukaan menunjukkan potensi adanya pergerakan air laut menuju daratan.

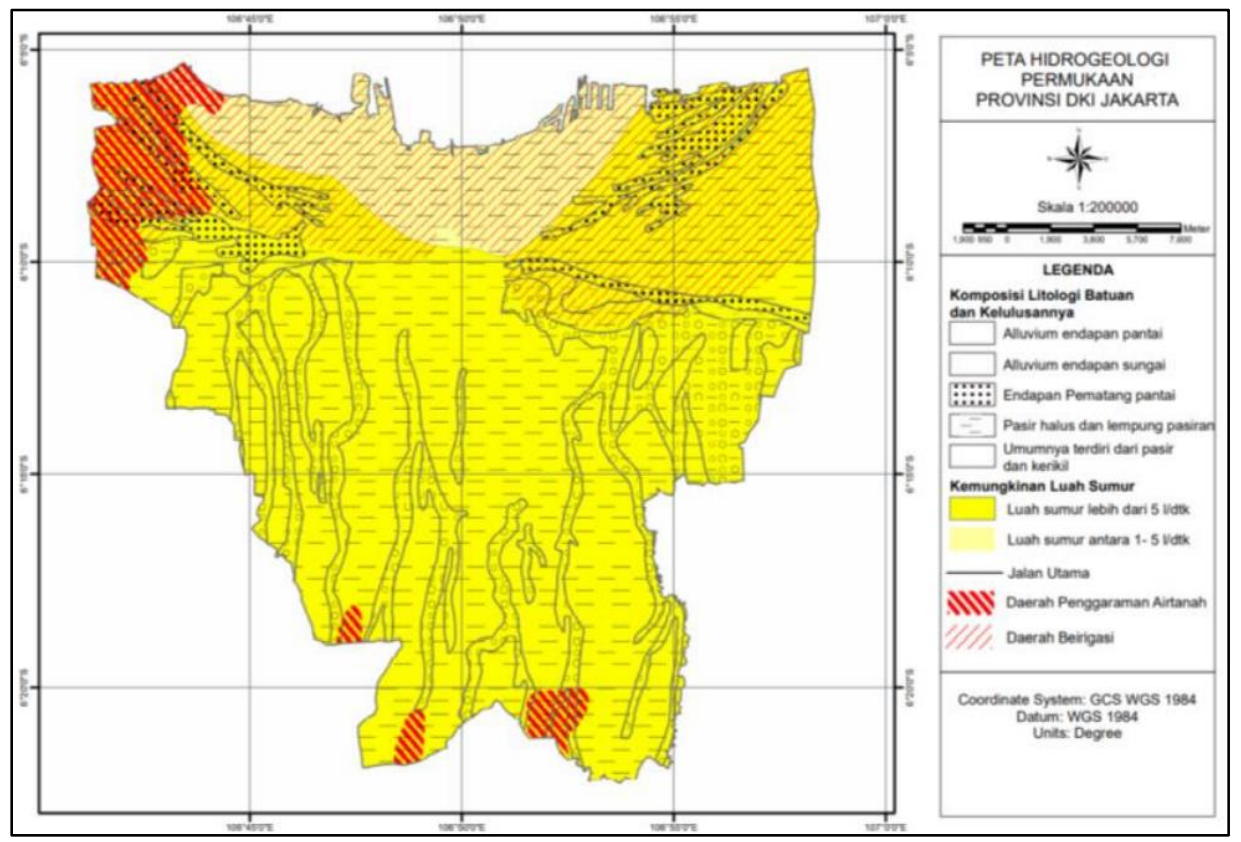

Gambar 6 Peta Hidrogeologi DKI Jakarta 


\section{Analisis Indeks Pencemaran Air Tanah}

Analisis indeks pencemaran air tanah di DKI Jakarta berdasarkan data yang diperoleh menunjukkan adanya kondisi wilayah dengan status kondisi baik, tercemar ringan, tercemar sedang dan tercemar berat (Tabel 1). Pengumpulan data dengan melakukan pengamatan dan perhitungan Indeks Pencemaran air tanah yang terdiri dari parameter fisika, kimia dan biologi yang terwakili oleh parameter dasar. Kondisi indeks pencemaran air tanah umumnya didominasi pada kondisi status pencemaran sedang (Gambar 7).

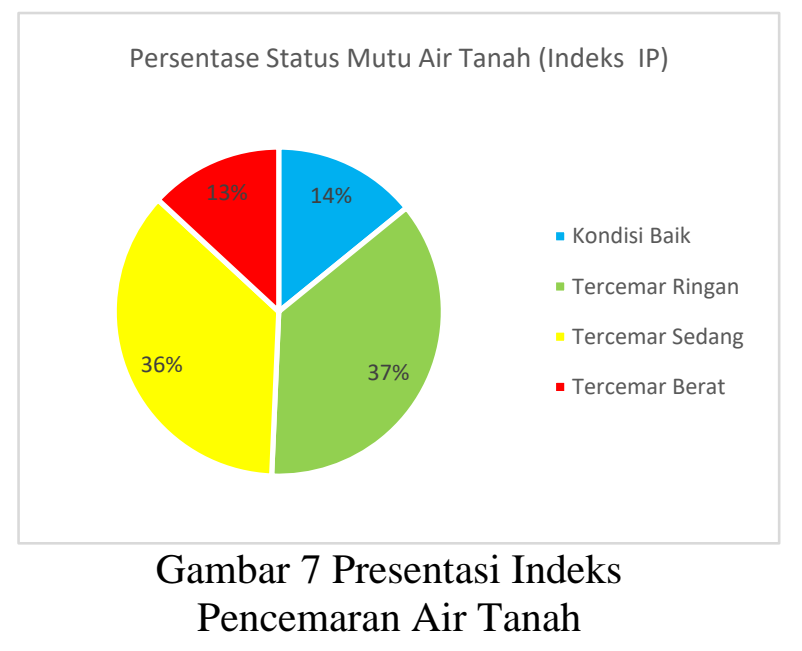

Analisis parameter kualitas air tanah berada pada kondisi air tanah bebas (uncofine aquifer). Hasil pengukuran parameter kekeruhan melampaui baku mutu terjadi di wilayah Jakarta Pusat dan Jakarta Utara. Hasil pengukuran warna yang melampaui baku mutu terjadi di wilayah Jakarta Utara dan Jakarta Selatan. Parameter TDS, pH dan Kesadahan melampaui baku mutu umumnya ditemukan di daerah Jakarta Utara yang dekat dengan pantai. Nilai DO atau Oksigen Terlarut ditemukan kecil pada daerah Jakarta Utara, hal ini berkorelasi positif dengan pengukuran dengan nilai $\mathrm{pH}$. Nilai $\mathrm{pH}$ semakin besar maka akan menyebabkan kondisi kelarutan oksigen dalam air akan menurun. Parameter biologis terdiri dari Total Coliform, nilai Total Coliform umumnya tinggi dijumpai pada beberapa wilayah dengan kepadatan penduduk sedang hingga tinggi. Nilai pengukuran parameter Total Coliform tinggi ditemukan pada wilayah Jakarta Utara, Sebagian Jakarta Timur dan Sebagian Jakarta Barat. Hasil pengukuran yang dilakukan dibandingkan dengan Permenkes No 32 Tahun 2017 Tentang Standar Baku Mutu Kesehatan Lingkungan dan Persyaratan Kesehatan Air Untuk Keperluan Higiene Sanitasi, Kolam Renang, Solus Per Aqua, dan Pemandian Umum.

\section{Analisis Pengaruh Lokasi Permukiman terhadap Indeks Pencemaran Air Tanah}

Hasil analisis permukiman dan lokasi pemantauan serta kualitas air tanah dievaluasi secara spasial dengan metode tumpang susun (overlay) dan analisis spasial (spatial analysis). Hasil overlay dari lokasi pemukiman dan lokasi titik pantau menunjukkan bahwa lokasi pemantauan sebagian besar bahkan hampir keseluruhan berada di lokasi pemukiman. Sehingga dengan informasi ini, data yang diperoleh pada lokasi pemantauan sudah menunjukkan pengaruh dari pemukiman terhadap hasil kualitas air tanah di wilayah tersebut. Hasil sebaran lokasi pemantauan dan pemukiman (Gambar 8). 


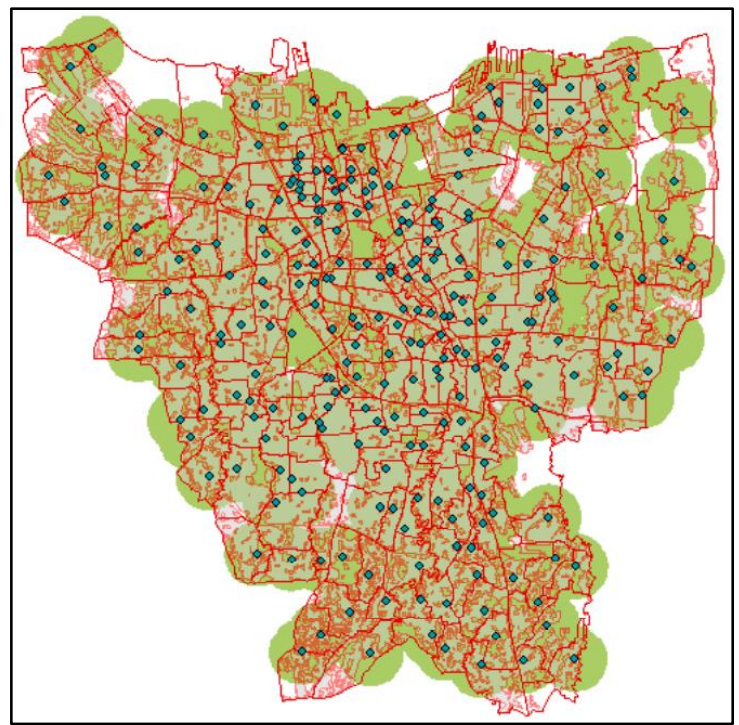

Gambar 8 Lokasi Pemukiman (abu-abu), Lokasi Titik Pantau (point) dan Buffer Jarak $1.5 \mathrm{~km}$ dari Titik Pantau (hijau muda)

Analisis terhadap pengaruh pemukiman terhadap kualitas air tanah dievaluasi dengan membandingkan lokasi pemukiman dengan nilai Indeks Pencemaran (IP) dari masing-masing wilayah yang sudah dikategorikan berdasarkan kategori tingkat pencemaran. Hasil analisis menunjukkan bahwa lokasi pemukiman berada pada wilayah-wilayah dengan kondisi kualitas air yang beragam yaitu kategori baik, cemar ringan, cemar sedang dan cemar berat. Hal ini menunjukkan bahwa lokasi pemukiman tidak memiliki korelasi yang signifikan terhadap kualitas air tanah (Gambar 9).

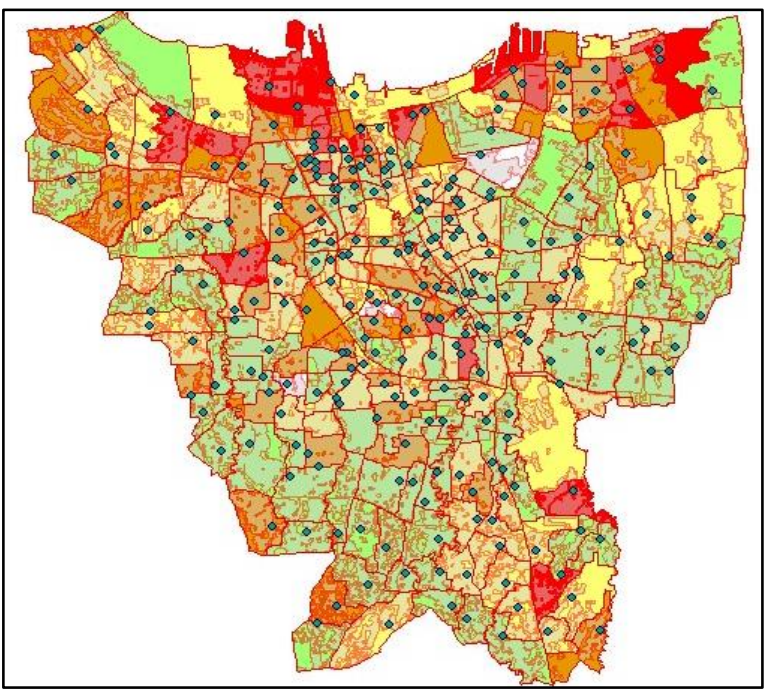

Gambar 9 Pengaruh Lokasi Pemukiman terhadap Indeks Pencemaran Kualitas Air tanah

\section{KESIMPULAN}

Hasil dari penelitian yang dilakukan di wilayah DKI Jakarta diantaranya :
1. Nilai Indeks pencemaran kualitas air tanah yang terdiri dari kondisi baik, tercemar ringan, tercemar ringan dan tercemar berat. Nilai indeks pencemaran air tanah umumnya 
tinggi pada wilayah Jakarta Utara dan Jakarta Pusat. Nilai indeks kualitas pencemaran tertinggi didapatkan sebesar 14.61.

2. Kualitas air tanah umumnya tidak terpengaruh pada permukiman di DKI Jakarta. Hasil menunjukkan tidak ada korelasi positif terhadap jumlah masyarakat dengan indeks pencemaran air tanah.

\section{DAFTAR PUSTAKA}

[Permen RI] Nomor 32 Tahun 2017 Tentang Standar Baku Mutu Kesehatan Lingkungan Dan Persyaratan Kesehatan Air Untuk Keperluan Higiene Sanitasi, Kolam Renang, Solus Per Aqua, Dan Pemandian Umum

Erwandha,Reza. 2021. Ex-Poste Study of Jakarta Flood Disasters from 2000 until 2019. Journal of Global Environmental Dynamics (JGED).Volume 2. 13-18.

Federica,Remondi.,Paolo,Burlando.,De rek,Vollmer. 2016. Exploring the hydrological impact of increasing urbanisation on a tropical river catchment of the metropolitan Jakarta, Indonesia. Elsevier. Volume 20.210-221

Hamidi, R., Furqon, M. T., dan B. Rahayudi. 2017. Implementasi Learning Vector Quantization (LVQ) untuk Klasifikasi Kualitas Air Sungai. Jurnal Pengembangan Teknologi Informasi dan Ilmu Komputer. 1(12): 1758-1763

Hamuna, B., Tanjung, R. H. R., Suwito, Maury, S. H. K., dan Alianto. 2018. Kajian Kualitas Air Laut dan Indeks Pencemaran Berdasarkan Parameter Fisika-Kimia Di Perairan Distrik Depapre, Jayapura. Jurnal Ilmu Lingkungan. 16(1): 35-43.
Hefni, Efendi. 2016. River Water Quality Preliminary Rapid Assessment Using Pollution Index.Elsevier.Volume 33.562567

Karamouz, K. 2011. Grounwater Hidrology. Engiinering, Planing and Management.New York.CRCPress

Prasetya,D.A. 2016. Prediksi Cadangan Air tanah Di Daerah Aliran Sungai Cisadane. Tesis Fakultas Teknologi Pertanian.IPB.

Quener, E.P. 2001. The Effect of Human Interventions on Groundwater Recharge. on Groundwater Dinamics. Proceeding of Sixth IAHS Scientific Assembly, July Paper in Impact of Human Activity 2001, Maastrict, Netherland. IAHS Publ. 269 : 59-56.

Setyaningrum, D. and L.. A. Rahmawati. 2020. Analisis Kualitas Air di Daerah Aliran Sungai Bengawan Solo Wilayah Kabupaten Bojonegoro. Samakia: Jurnal Ilmu Perikanan. 11(1): 1-9.

Youn, ShikPark.,Bernie, A Engel. 2015. A Web Tool for STORET/WQX Water Quality Data Retieval and Best Management Practice Scenario Suggestion. Elsevier. Volume 150. 21-27.

Wibisono,AT. 2021. Water Pollution Identification and Mitigation at Several Points of Bengawan Solo River. Journal of Global Environmental Dynamics (JGED).Volume 2. 1-3 